Research Article

\title{
VDR polymorphisms influence immunological response in HIV-1+ individuals undergoing antiretroviral therapy
}

\author{
Ronaldo Celerino da Silva ${ }^{{ }^{*}}$ (D), Neyla Maria Pereira Alves ${ }^{1,2^{*}}$, Jorge José de Souza Pereira ${ }^{1,3}$, Antonio \\ Victor Campos Coelho ${ }^{1,3}$, Luiz Cláudio Arraes ${ }^{4}$, Lucas André Cavalcanti Brandão ${ }^{1,2}$, Sergio Crovella ${ }^{1,3}$ (i) \\ and Jaqueline de Azevêdo Silva ${ }^{1,3}$ \\ ${ }^{1}$ Laboratorio de Immunopatologyia Keizo Asami (LIKA), Universidade Federal de Pernambuco, Recife, PE, \\ Brazil. \\ ${ }^{2}$ Departamento of Patologia, Universidade Federal de Pernambuco, Recife, PE, Brazil. \\ ${ }^{3}$ Departamento de Genética, Universidade Federal de Pernambuco, Recife, PE, Brazil. \\ ${ }^{4}$ Instituto de Medicina Integral de Pernambuco Professor Fernando Figueira, Recife, PE, Brazil.
}

\begin{abstract}
Vitamin D exerts an immuno-modulatory activity on several immune system cells through the vitamin $D$ receptor (VDR). Herein, we verified that age and a therapeutic regimen containing protease inhibitors are associated with failures in antiretroviral therapies (ARVs). In addition, we assessed whether a VDR SNP (rs11568820: C allele and CC genotype) and GC (rs2228570-rs11568820) allelic combinations are associated with immunological failure ( $p<$ 0.05). Our findings suggest a possible role of VDR SNPs on immunological failure in HIV-1+ individuals undergoing regular ARVs.
\end{abstract}

Keywords: VDR, HIV-1, ARVs, SNPs, CD4 recovery.

Received: September 18, 2017; Accepted: August 14, 2018.

Antiretroviral therapies (ARVs) have changed the landscape of Human Immunodeficiency Virus (HIV) treatment in the last years. ARVs act by boosting immune functions and reducing morbidity and mortality by suppressing viral replication (Palella et al., 2006). There is no "one fits all" therapy, since some individuals receiving ARVs are not able to suppress the viral load to undetectable levels as expected (virological failure) (Coelho et al., 2013). On the other hand, some individuals with undetectable viral load, cannot recover the quasi-normal CD4+ T-cell count (immunological failure) (Kelley et al., 2009). These phenomena might be due to the hosts' genetics, immunological factors, and viral profiles (Geretti et al., 2009; Robbins et al., 2009).

1,25-dihydroxy vitamin $\mathrm{D}\left(1,25[\mathrm{OH}]_{2} \mathrm{D}\right)$ exerts potent immunologic roles in both innate and adaptive responses. Its binding with vitamin D receptor (VDR) promotes a series of intracellular events culminating in the modulation of expression levels of various target genes. These effects may promote the control of intracellular pa-

Send correspondence to Dr. Ronaldo Celerino da Silva. Laboratory of Immunopathology Keizo Asami (LIKA), Department of Genetics, Federal University of Pernambuco (UFPE), Av. Prof. Moraes Rego,1235, 50.670-901 Recife, PE, Brazil. E-mail: ronaldocelerino@yahoo.com.br

*These authors contributed equally to this study. thogens, mainly by producing antimicrobial peptides, and stimulating phagocytic activity in macrophages (Prietl et al., 2013).

In HIV-1 infection, variable levels of $1,25[\mathrm{OH}]_{2} \mathrm{D}$ may decrease the immune system activation during the acute phase, or induce a less effective T-helper lymphocyte response throughout the chronic phase (Appay and Sauce, 2008; Giusti and Penco, 2011). Indeed, individuals with adequate levels of this vitamin, have been seen to better counteract HIV replication (Lake and Adams, 2011).

In addition, ARVs may alter the circulating levels of 25 -hydroxy vitamin D $(25[\mathrm{OH}] \mathrm{D})\left(1,25[\mathrm{OH}]_{2} \mathrm{D}\right.$ metabolic precursor), as these compounds share common cytochrome P450 enzymes involved in their synthesis $\left(1,25[\mathrm{OH}]_{2} \mathrm{D}\right)$ and excretory (ARVs) metabolic pathways (Mueller et al., 2010; Welz et al., 2010). Interestingly, $1,25[\mathrm{OH}]_{2} \mathrm{D}$ insufficiency/deficiency has been associated with the usage of ARVs (Cozzolino et al., 2003; Brown and McComsey, 2010).

Single nucleotide polymorphisms (SNPs) in the $V D R$ gene (12q13.11) have been associated to susceptibility and progression of HIV/AIDS, since they may alter gene function and compromise the role of $1,25[\mathrm{OH}]_{2} \mathrm{D}$ (de la Torre $e t$ al., 2008; Alagarasu et al., 2009; Aguilar-Jiménez et al., 2013; Laplana et al., 2014). However, there are no reports 
associating these genetic variants with successful treatment and immune recovery.

In this work, we investigated the distribution of $V D R$ SNPs in HIV-1 infected individuals (HIV-1+) to unravel their relation with treatment response and immune recovery.

We analyzed 195 HIV-1+ individuals from Recife and minor towns of the state of Pernambuco (Northeastern Brazil), recruited from 2011 to 2014 at the Institute of Integral Medicine Professor Fernando Figueira (Human Research Ethics Committee register nr. 2629-13). Individuals lacking pre-existing viral hepatitis co-infection, and who have adhered for at least one year to ARVs have been selected for this study (Coelho et al., 2013). The studied population was stratified into 132 individuals with undetectable viral load $(<50$ copies $/ \mathrm{mL}$ ) (virological success/suppression) and 63 individuals having detectable viral load ( $>50$ copies $/ \mathrm{mL}$ ) (virological failure). In addition, based on the comparison between CD4+ T-cell count before treatment (baseline) and after one year of treatment $(\mathrm{Li}$ et al., 2011), individuals possessing virological suppression were divided as immunological success (65) (recovery of CD4+> 200 cells $/ \mathrm{mm}^{3}$ ) and immunological failure (67) (non-recovery CD4 $+<200$ cells $/ \mathrm{mm}^{3}$ ).

Individuals manifesting virological failure were mostly female $(66.7 \%)$, with a median age of 35 years ( $p=0.009$, Mann-Whitney test), and receiving therapeutic regimens containing protease inhibitors (2 non-nucleoside reverse transcriptase inhibitor + protease inhibitor [NNRTI+PI]; 55.6\%, $p=0.037$, Chi-square test). Furthermore, the NNRTI-containing regimen resulted more frequently in individuals with immunological failure (68.7\%) in comparison to the immunological successful ones (53.1\%, $p=0.047$, Chi-square test) (Table 1).

Studies in Latin American populations (Bello et al., 2011; Alave et al., 2013; Cesar et al., 2015) also identified as risk factors for virological failure parameters such as younger age (20 years), infection pathway (Cesar et al., 2015), antiretroviral use history before starting a new therapy regimen, therapy change due to toxicity, opportunistic infections, baseline CD4+ T-cells count below 100 cells $/ \mu \mathrm{L}$, adherence, advanced clinical stage (Alave et al., 2013), geographical origin, and Mycobacterium tuberculosis co-infection (Bello et al., 2011).

Besides the clinical-epidemiological characteristics, a panel of four tag-SNPs in the intronic region within the $V D R$ gene (rs3890733, rs4760648, rs1540339, rs2248098) and two functional ones, namely rs2228570 (Fok1 - missense variation - stat lost) and rs 11568820 (Cdx2 - regulatory variation) were studied. SNP selection was based on public data bank as well as literature data (de la Torre et al., 2008; Alagarasu et al., 2009; Laplana et al., 2014; Xu et al., 2015). All variants were genotyped using allele-specific fluorogenic probes by real-time PCR and presented minor allele frequency $(\mathrm{MAF}) \geq 10 \%$ in Caucasian (CEU) and

Table 1 - Clinical and Epidemiological characteristics of the study population.

\begin{tabular}{|c|c|c|c|c|c|c|}
\hline \multirow[b]{2}{*}{ Characteristics } & \multicolumn{3}{|c|}{ Virologic Response } & \multicolumn{3}{|c|}{ Immunological Response } \\
\hline & Success $(n=132)$ & Failure $(n=63)$ & Univariate analysis & Success $(n=65)$ & Failure $(n=67)$ & Univariate analysis \\
\hline \multicolumn{7}{|l|}{ Sex, n (\%) } \\
\hline Female & $72(54.5)$ & $42(66.7)$ & $\begin{array}{c}\mathrm{X}^{2}=2.1052, \mathrm{df}=1, \\
p \text {-value }=0.147\end{array}$ & $40(61.5)$ & $32(47.8)$ & $\begin{array}{c}\mathrm{X}^{2}=1.7736, \mathrm{df}=1, \\
p \text {-value }=0.183\end{array}$ \\
\hline Male & $60(45.5)$ & $21(33.3)$ & & $25(38.5)$ & $35(52.2)$ & \\
\hline \multicolumn{7}{|l|}{ Age } \\
\hline Median years (IQR) & $\begin{array}{c}38.0 \\
(34.0-46.0)\end{array}$ & $\begin{array}{c}35.0 \\
(31.5-41.0)\end{array}$ & $\begin{array}{c}\mathrm{W}=3201, \\
p \text {-value }=0.009 *\end{array}$ & $\begin{array}{c}37.0 \\
(34.0-46.0)\end{array}$ & $\begin{array}{c}38.0 \\
(34.0-45.0)\end{array}$ & $\begin{array}{c}\mathrm{W}=2015 \\
p \text {-value }=0.528\end{array}$ \\
\hline \multicolumn{7}{|l|}{ Weight } \\
\hline Median kilograms (IQR) & $\begin{array}{c}62.0 \\
(54.2-74.0)\end{array}$ & $\begin{array}{c}62.7 \\
(55.0-73.2)\end{array}$ & $\begin{array}{c}\mathrm{W}=4043.5 \\
p \text {-value }=0.500\end{array}$ & $\begin{array}{c}63.0 \\
(53.0-74.0)\end{array}$ & $\begin{array}{c}62.0 \\
(56.0-74.0)\end{array}$ & $\begin{array}{c}\mathrm{W}=1858, \\
p \text {-value }=0.630\end{array}$ \\
\hline \multicolumn{7}{|l|}{ Baseline viral load } \\
\hline Median $\log 10$ copies/mL(IQR) & $\begin{array}{c}4.40 \\
(3.02-5.10)\end{array}$ & $\begin{array}{c}3.78 \\
(2.85-4.91)\end{array}$ & $\begin{array}{c}\mathrm{W}=3417.5, \\
p \text {-value }=0.526\end{array}$ & $\begin{array}{c}4.52 \\
(3.68-5.06)\end{array}$ & $\begin{array}{c}4.31 \\
(2.36-5.11)\end{array}$ & $\begin{array}{c}\mathrm{W}=1741, \\
p \text {-value }=0.451\end{array}$ \\
\hline \multicolumn{7}{|l|}{$\mathrm{CD} 4+\mathrm{T}$ cells count baseline } \\
\hline Median cells $/ \mathrm{mm}^{3}$ (IQR) & $\begin{array}{c}282.0 \\
(165.0-365.0)\end{array}$ & $\begin{array}{c}291.0 \\
(179.0-410.0)\end{array}$ & $\begin{array}{c}\mathrm{W}=3883, \\
p \text {-value }=0.769\end{array}$ & $\begin{array}{c}282 \\
(200.5-433.0)\end{array}$ & $\begin{array}{c}282.5 \\
(126.0-343.7)\end{array}$ & $\begin{array}{c}\mathrm{W}=1567, \\
p \text {-value }=0.178\end{array}$ \\
\hline \multicolumn{7}{|l|}{ HAART regimens, $\mathrm{n}(\%)$} \\
\hline NNRTI use & $80(61.1)$ & $28(44.4)$ & $\begin{array}{c}\mathrm{X}^{2}=4.3617, \mathrm{df}=1 \\
p \text {-value }=0.037^{*}\end{array}$ & $32(53.1)$ & $43(68.7)$ & $\begin{array}{c}\mathrm{X}^{2}=3.9558, \mathrm{df}=1 \\
p \text {-value }=0.047^{*}\end{array}$ \\
\hline PI use & $50(38.9)$ & $35(55.6)$ & & $29(46.9)$ & $17(31.3)$ & \\
\hline
\end{tabular}

$\mathrm{n}=$ Sample size; $\mathrm{IQR}=$ Interquartile range; $\mathrm{X}^{2}=$ Result from chi-squared test; $\mathrm{df}=$ Degrees of freedom; $\mathrm{W}=$ Result from Mann-Whitney test; * = Significant $p$-value. 
Yoruba (YRI) populations, considering them as proxies to Brazil's ancestral populations (Coelho et al., 2015).

Allelic and genotypic frequencies of $V D R$ SNPs in treatment and immunological response groups are reported in Table 1. All the considered SNPs studied were in accordance with Hardy-Weinberg equilibrium in all groups, except for SNP rs3890733. No significant differences were observed for the tested SNPs relative to treatment response, but the SNP rs11568820 (C > T) was found to be associated with immune recovery.

The $\mathrm{C}$ allele (rs11568820) was significantly more frequent in individuals presenting immunological failure (62.1\%), rather than in those showing immunological success $(48.4 \%$; OR $=1.74 ; 95 \% \mathrm{CI}=1.01-3.03 ; p=0.037$, Fisher's exact test). Similarly, the $\mathrm{C} / \mathrm{C}$ genotype was significantly more frequent in immunological failure (34.5\%) in comparison to individuals with immunological success $(19.7 \%$; OR=3.78; $95 \% \mathrm{CI}=1.03-15.57 ; p=0.045$, Fisher's exact test) (Table 2).

No haplotype block was observed for $V D R$ functional SNPs in all studied groups (D'>0.20). Allelic combination analyses revealed that only the GC allele combination (rs2228570-rs11568820) was associated with immunological failure $(\mathrm{OR}=2.19 ; 95 \% \mathrm{CI}=1.09-4.45 ; p=0.023$, Fisher's exact test) (Table S1).

Two multivariate analyses were performed containing variables with $p \leq 0.2$ obtained during univariate analyses. Age, gender, antiretroviral drugs classes, and rs2248098 genotypes were included as clinic-epidemiological and genetic variables to assess whether they influenced the overall virological response, but no significant associations were found. The second analysis included the pre-treatment (baseline) CD4+ T-cells count, gender, and antiretroviral drugs classes. In the second multivariate analysis we intended to assess whether rs2248098 and rs11568820 genotypes had any influence on immunological response. Again, the rs $11568820 \mathrm{C} / \mathrm{C}$ genotype was associated with immunological failure $(\mathrm{OR}=6.00$; $95 \% \mathrm{CI}=1.52-23.72 ; p$-value $=0.01)($ Table S2$)$.

None of the studied SNPs were involved in viral load control before treatment and CD4+ T-cell count baseline, even when classified according to virological treatment response or immunological recovery ( $p$-values $>0.05$; Kruskal-Wallis test, data not shown).

The $\mathrm{C}$ allele and $\mathrm{C} / \mathrm{C}$ genotype of SNP rs11568820 and the GC allelic combination (rs2228570-rs11568820) were associated with immunological failure in individuals that achieved the viral load suppression following ARVs. The understanding of this immunological impairment in viral-suppressed HIV-1 individuals remains elusive mainly due to its multifactorial character. In our work, we addressed a SNP as a candidate for contributing in the immune recovery modulation. The rs 11568820 SNP (known as $(\mathrm{dx}-2)$, located within the VDR promoter region, acts at the transcriptional level. Therefore, the presence of the $\mathrm{C}$ allele (rs11568820) may result in a decreased transcriptional activity and, consequently, in lower VDR expression (Arai et al., 2001).

Finally, the levels of 25(OH)D in plasma were obtained from medical records of 31 individuals deriving from our sample groups (19 immunological success and 12 immunological failure). A Cochran-Mantel-Haenszel test was applied to assess whether the interaction between $25(\mathrm{OH})$ D plasma levels and VDR genotypes had an impact on immunological failure risk, thus following the hypothesis that some VDR genotypes would not respond to $25(\mathrm{OH}) \mathrm{D}$ levels, even if they are adequate. However, no significant differences were found (success group median=35.2, IQR=28.1-41.1; failure group median=32.9, $\mathrm{IQR}=31.4-41.0 ; \mathrm{W}=109 ; p$-value $=0.86$, Table S3). Next, we stratified the individuals according to $V D R$ genotypes and insufficient/sufficient status and evaluated, through a Cochran-Mantel-Haenszel test, whether the genotypes versus $25(\mathrm{OH}) \mathrm{D}$ influenced the risk of immunological failure. Also in this case, no associations were observed. Even deficient 25(OH)D levels have been found not to be associated with immunological failure, irrespective of VDR genotype (data not shown).

We did not identify relationships between plasma levels and immunological failure, in spite of a $V D R$-associated genotype (rs11568820). This fact may be related to the small number of individuals used in the dosage and/or the absence of a proper classification of studied individuals referred to the infection stage, which in our population is almost impossible to perform, since the vast majority of HIV infected cases have a late diagnosis, thus arriving at health services presumably in a chronic stage, and finally the lack of control regarding seasonal variation in vitamin D. In our cohort it is assumed that such inter-individual variation is small, as there is a regular incidence of solar rays in the geographic region.

Nonetheless, we believe that individuals with immunological failure and $V D R$ genotype (CC - rs11568820), related to low expression of $V D R$, can impair $1,25[\mathrm{OH}]_{2} \mathrm{D}$ action, since its activity occurs through VDR binding (Selvaraj et al., 2012). A reduced $1,25[\mathrm{OH}]_{2} \mathrm{D}$ activity compromises cell-mediated immune response, phagocytic activity in macrophages (Deluca and Cantorna 2001; Prietl et al., 2013), suppresses T-cell activation, downregulates pro-inflammatory cytokine production, and decreases anti-microbial defence by peptides, which in turn impair viral replication (Beard et al., 2011).

Furthermore, Chandel et al. (2013) demonstrated that down-regulation of VDR expression in T-cells deriving from HIV-1+ individuals is due to hypermethylation in the promoter region. These epigenetic alterations increase the activation of the renin angiotensin system (RAS) and reactive oxygen species (ROS) production, inducing doublestrand breaks (DSBs) and attenuated DNA repair response, therefore favouring T-cell apoptosis. 
Table 2 - Allelic and genotypic frequencies of VDR SNPs in HIV-1+ patients in HAART treatment as to the virological and immunological response.

\begin{tabular}{|c|c|c|c|c|c|c|}
\hline \multirow[t]{2}{*}{ SNPs } & \multicolumn{2}{|c|}{ Virological } & \multirow{2}{*}{$\begin{array}{l}\text { Fisher's Exact Test } \\
\text { OR }(95 \% \mathrm{CI}), p \text {-value }\end{array}$} & \multicolumn{2}{|c|}{ Immunological } & \multirow{2}{*}{$\begin{array}{l}\text { Fisher's Exact Test } \\
\text { OR }(95 \% \mathrm{CI}), p \text {-value }\end{array}$} \\
\hline & Success n $(\%)$ & Failure n (\%) & & Success n $(\%)$ & Failure n $(\%)$ & \\
\hline \multicolumn{7}{|c|}{ rs2248098 } \\
\hline G & $125(54.3)$ & $52(46.4)$ & Reference & $62(55.4)$ & $63(53.4)$ & Reference \\
\hline A & $105(45.7)$ & $60(53.6)$ & 1.37 (0.85-2.22), 0.205 & $50(44.6)$ & $55(46.6)$ & $1.08(0.62-1.88), 0.792$ \\
\hline GG & $34(29.6)$ & $12(21.4)$ & Reference & $20(35.7)$ & $14(23.7)$ & Reference \\
\hline GA & $57(49.6)$ & $28(50.0)$ & $1.39(0.59-3.41), 0.551$ & $22(39.3)$ & $35(59.3)$ & $2.25(0.88-5.93), 0.082$ \\
\hline AA & $24(20.9)$ & $16(28.6)$ & $1.87(0.69-5.22), 0.249$ & $14(25.0)$ & $10(16.9)$ & $1.02(0.31-3.34), 1.000$ \\
\hline \multicolumn{7}{|c|}{ rs 1540339} \\
\hline $\mathrm{C}$ & $167(69.6)$ & $77(67.5)$ & Reference & $85(70.8)$ & $82(68.3)$ & Reference \\
\hline $\mathrm{T}$ & $73(30.4)$ & $37(32.5)$ & $1.10(0.66-1.82), 0.713$ & $35(29.2)$ & $38(31.7)$ & $1.12(0.62-2.03), 0.779$ \\
\hline $\mathrm{CC}$ & $59(49.2)$ & $28(49.1)$ & Reference & $31(51.7)$ & $28(46.7)$ & Reference \\
\hline $\mathrm{CT}$ & $49(40.8)$ & $21(36.8)$ & $0.90(0.43-1.88), 0.863$ & $23(38.3)$ & $26(43.3)$ & $1.25(0.55-2.86), 0.699$ \\
\hline $\mathrm{TT}$ & $12(10.0)$ & $8(14.0)$ & $1.40(0.44-4.23), 0.601$ & $6(10.0)$ & $6(10.0)$ & $1.10(0.26-4.67), 1.000$ \\
\hline \multicolumn{7}{|c|}{ rs2228570 } \\
\hline G & $180(69.8)$ & $87(71.3)$ & Reference & $83(65.9)$ & $97(73.5)$ & Reference \\
\hline A & $78(30.2)$ & $35(28.7)$ & $0.93(0.56-1.52), 0.811$ & $43(34.1)$ & $35(26.5)$ & $0.70(0.39-1.23), 0.222$ \\
\hline GG & $63(48.8)$ & $29(47.5)$ & Reference & 27 (42.9) & $36(37.9)$ & Reference \\
\hline GA & $54(41.9)$ & $29(47.5)$ & $1.16(0.59-2.30), 0.748$ & $29(46.0)$ & $25(37.9)$ & $0.65(0.29-1.43), 0.269$ \\
\hline AA & $12(9.3)$ & $3(4.9)$ & $0.54(0.09-2.24), 0.545$ & $7(11.1)$ & $5(7.6)$ & $0.54(0.12-2.22), 0.359$ \\
\hline \multicolumn{7}{|c|}{ rs4760648 } \\
\hline $\mathrm{T}$ & $98(53.3)$ & $40(58.8)$ & Reference & $52(55.3)$ & $46(51.1)$ & Reference \\
\hline $\mathrm{C}$ & $86(46.7)$ & $28(41.2)$ & $0.80(0.43-1.45), 0.477$ & $42(44.7)$ & $44(48.9)$ & $1.18(0.66-2.20), 0.658$ \\
\hline TT & $26(28.3)$ & $13(38.2)$ & Reference & $14(29.8)$ & $12(26.7)$ & Reference \\
\hline $\mathrm{TC}$ & $46(50.0)$ & $14(41.2)$ & $0.61(0.23-1.65), 0.356$ & $24(51.1)$ & $22(48.9)$ & $1.07(0.37-3.14), 1.000$ \\
\hline $\mathrm{CC}$ & $20(21.7)$ & $7(20.6)$ & $0.70(0.20-2.33), 0.593$ & $9(19.1)$ & $11(24.4)$ & $1.41(0.38-5.39), 0.767$ \\
\hline \multicolumn{7}{|c|}{ rs3890733 § } \\
\hline $\mathrm{C}$ & $149(64.8)$ & $67(67.0)$ & Reference & $78(67.2)$ & $71(62.3)$ & Reference \\
\hline $\mathrm{T}$ & $81(35.2)$ & $33(33.0)$ & $0.91(0.53-1.53), 0.801$ & $38(32.8)$ & $43(37.7)$ & $1.24(0.70-2.22), 0.490$ \\
\hline $\mathrm{CC}$ & $58(50.4)$ & $26(52.0)$ & Reference & $32(55.2)$ & $26(45.6)$ & Reference \\
\hline $\mathrm{CT}$ & $33(28.7)$ & $15(30.0)$ & $1.01(0.43-2.32), 1.000$ & $14(24.1)$ & $19(33.3)$ & $1.66(0.65-4.34), 0.280$ \\
\hline TT & $24(20.9)$ & $9(18.0)$ & 0.84 (0.30-2.19), 0.824 & $12(20.7)$ & $12(21.1)$ & $1.23(0.42-3.56), 0.808$ \\
\hline \multicolumn{7}{|c|}{ rs11568820 } \\
\hline $\mathrm{T}$ & $109(45.4)$ & $50(46.3)$ & Reference & $63(51.6)$ & $44(37.9)$ & Reference \\
\hline $\mathrm{C}$ & $131(54.6)$ & $58(53.7)$ & $0.96(0.60-1.56), 0.908$ & $59(48.4)$ & $72(62.1)$ & $1.74(1.01-3.03), 0.037 *$ \\
\hline TT & $21(17.5)$ & $12(22.2)$ & Reference & $14(23.0)$ & $6(10.3)$ & Reference \\
\hline $\mathrm{CT}$ & $67(55.8)$ & $26(48.1)$ & $0.68(0.27-1.75), 0.384$ & $35(57.4)$ & $32(55.2)$ & $2.11(0.66-7.56), 0.203$ \\
\hline $\mathrm{CC}$ & $32(26.7)$ & $16(29.6)$ & $0.88(0.31-2.47), 0.815$ & $12(19.7)$ & $20(34.5)$ & $3.78(1.03-15.57), 0.045^{*}$ \\
\hline
\end{tabular}

$\mathrm{n}=$ Sample size; OR = Odds ratios; 95\% CI = 95\% Confidence interval; * = significant $p$-value; $\S=$ not Hardy-Weinberg Equilibrium.

ARVs themselves might further compromise the action of $1,25[\mathrm{OH}]_{2} \mathrm{D}$, since some antiretroviral drugs (efavirenz, tenofovir and ritonavir) have been associated with changes in plasma levels of $1,25[\mathrm{OH}]_{2} \mathrm{D}$ (Welz et al., 2010; Dao et al., 2011). In our cohort, amongst individuals with available dosage, we observed that $50 \%$ of the cases 

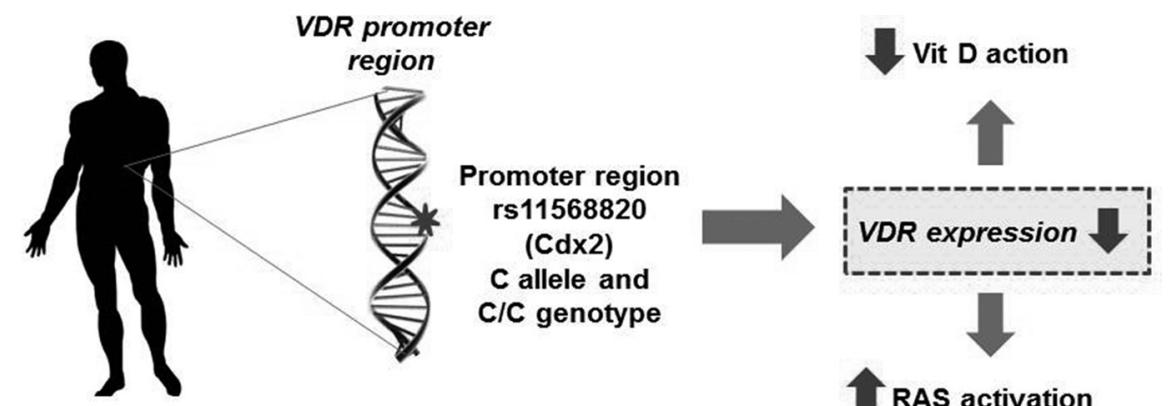

HIV-infected on antiretroviral therapy
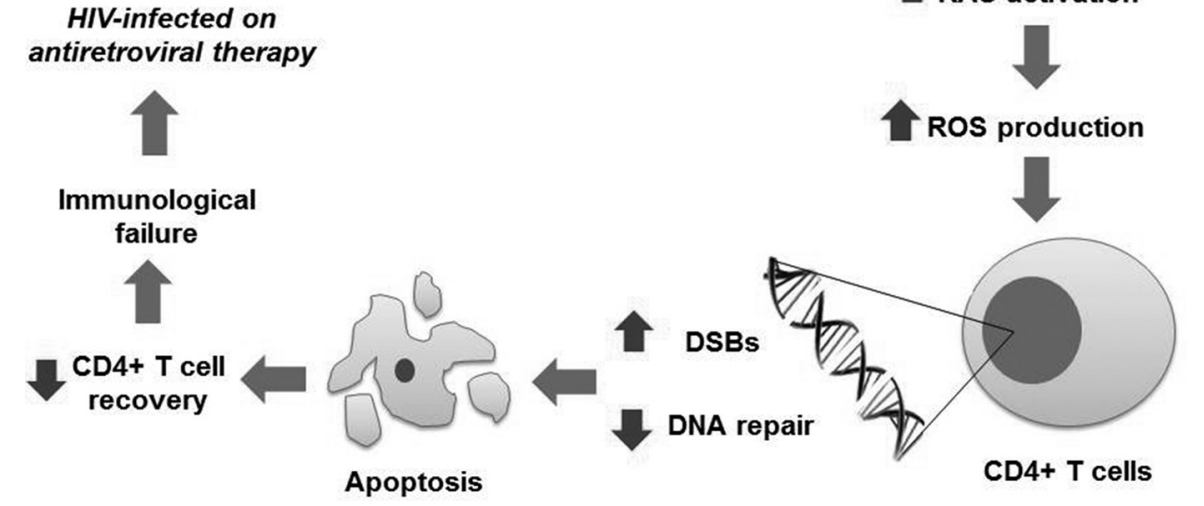

Figure 1 - Hypothetical model of the VDR receptor involvement in HIV-infected individuals treated with antiretroviral therapy and showing immunological failure.

showing immunological failure used a NNTRI-containing regimen and $50 \%$ received a PI-containing treatment. Among the individuals with immunological success, approximately $42 \%$ used a NNTRI-containing therapy, against 58\% who used PI.

We cannot fail to recognize our limitations. Firstly, the small sample number is directly linked to the individuals treatment adherence. Despite a large number of patients undergoing treatment, the majority had low ARVs adherence. Secondly, for some SNPs the number of genotyped individuals resulted different in relations to others due to the quality of the biological samples, implying technical difficulties in the genotyping process. A further limitation was due to the lack of VDR expression analysis caused by the impossibility to extract RNA from certain biological samples.

In conclusion, our results lead us to hypothesize (Figure 1) that genetic variations in VDR (rs11568820 - C allele and $\mathrm{C} / \mathrm{C}$ genotype; $\mathrm{CG}$ allelic combination) might decrease VDR expression, influencing the binding of $1,25[\mathrm{OH}]_{2} \mathrm{D}$ to VDR (possibly disrupting the $1,25[\mathrm{OH}]_{2} \mathrm{D}$ action) and inducing apoptosis, consequently affecting CD4+ T-cells recovery. Our work reports for the first time the existence of a relationship between SNPs in the VDR gene and the immunological recovery in HIV-1 + individuals undergoing ARVs.

\section{Acknowledgments}

We thank all individuals involved in this study and the IMIP-PE. This research received funding from Fun- dação de Amparo à Ciência e Tecnologia do Estado de Pernambuco (FACEPE) (APQ-0599-2.02/14) and through a Programa Nacional de Pós-Doutorado (PNPD) grant from Coordenação de Aperfeiçoamento de Pessoal de Nível Superior - Brasil (CAPES) - Finance Code 001 .

\section{Conflict of interest}

The authors declare no conflict of interest.

\section{Author contributions}

RCS, conceived, designed, conducted the experiments, analyzed the data and wrote the manuscript; NMPA, conducted the experiments and wrote the manuscript, JJSP, conducted the experiments, AVCC, analyzed the data, LCA, LACB and SC, critically analyzed the data and contributed in manuscript writing and JAS, conceived, designed the study, critically analized the data and manuscript writing. All authors read and approved the final version.

\section{References}

Aguilar-Jiménez W, Zapata W, Caruz A and Rugeles MT (2013) High transcript levels of vitamin D receptor are correlated with higher mRNA expression of human beta defensins and IL-10 in Mucosa of HIV-1-exposed seronegative individuals. PLoS One 8:e82717.

Alagarasu K, Selvaraj P, Swaminathan S, Narendran G and Narayanan PR (2009) 5' regulatory and 3' untranslated region polymorphisms of vitamin D receptor gene in south Indian HIV and HIV-TB patients. J Clin Immunol 29:196-204.

Alave J, Paz J, González E, Campos M, Rodríguez M, Willig J and Echevarría J (2013) Risk factors associated with virologic 
failure in HIV- infected patients receiving antiretroviral therapy at a public hospital in Peru. Rev Chilena Infectol 30:42-48.

Appay V and Sauce D (2008) Immune activation and inflammation in HIV-1 infection: causes and consequences. J Pathol 214:231-241.

Arai H, Miyamoto KI, Yoshida M, Yamamoto H, Taketani Y, Morita K, Kubota M, Yoshida S, Ikeda M, Watabe F et al. (2001) The polymorphism in the caudal-related homeodomain protein $\mathrm{Cdx}-2$ binding element in the human vitamin $\mathrm{D}$ receptor gene. J Bone Min Res 16:1256-1264.

Beard JA, Bearden A and Striker R (2011) Vitamin D and the anti-viral state. J Clin Virol 50:194-200.

Bello EJM, Correia AF, Marins JRP, Merchan-Hamann E and Kanzaki LIB (2011) Predictors of virologic failure in HIV/AIDS patients treated with highly active antiretroviral therapy in Brasilia, Brazil, during 2002-2008. Drug Target Insights 5:33-41.

Brown T and McComsey G (2010) Association between initiation of anti-retroviral therapy with efavirenz and decreases in 25-hydroxyvitamin. Antivir Ther 15:425-9.

Cesar C, Jenkins CA, Shepherd BE, Padgett D, Mejía F, Ribeiro SR, Cortes CP, Pape JW, Madero JS, Fink V et al. (2015) Incidence of virological failure and major regimen change of initial combination antiretroviral therapy in the Latin America and the Caribbean: An observational cohort study. Lancet HIV 2:e492-e500.

Chandel N, Husain M, Goel H, Salhan D, Lan X, Malhotra A, McGowan J and Singhal PC (2013) VDR hypermethylation and HIV-induced T cell loss. J Leukoc Biol 93:623-31.

Coelho AVC, Silva SPS, de Alencar LC, Stocco G, Crovella S, Brandão LA and Guimarães RL (2013) ABCB1 and ABCC1 variants associated with virological failure of first-line protease inhibitors antiretroviral regimens in Northeast Brazil patients. J Clin Pharmacol 53:1286-1293.

Coelho A, Moura R, Cavalcanti C, Guimaraes R, Sandrin-Garcia P, Crovella S and Brandão LAC (2015) A rapid screening of ancestry for genetic association studies in an admixed population from Pernambuco, Brazil. Genet Mol Res 14:2876-2884

Cozzolino M, Vidal M, Arcidiacono MV, Tebas P, Yarasheski KE and Dusso AS (2003) HIV-protease inhibitors impair vitamin $\mathrm{D}$ bioactivation to 1,25-dihydroxyvitamin D. Aids 17:513-520.

Dao CN, Patel P, Overton ET, Rhame F, Pals SL, Johnson C, Bush $\mathrm{T}$ and Brooks JT (2011) Low vitamin D among HIV-infected adults: Prevalence of and risk factors for low vitamin D levels in a cohort of HIV-infected adults and comparison to prevalence among adults in the us general population. Clin Infect Dis 52:396-405.

De La Torre MS, Torres C, Nieto G, Vergara S, Carrero AJ, Macías J, Pineda JA, Caruz A and Fibla J (2008) Vitamin D receptor gene haplotypes and susceptibility to HIV-1 infection in injection drug users. J Infect Dis 197:405-10.

Deluca HF and Cantorna MT (2001) Vitamin D: Its role and uses in immunology. FASEB J 15:2579-2585.

Geretti AM, Harrison L, Green H, Sabin C, Hill T, Fearnhill E, Pillay D and Dunn D (2009) Effect of HIV-1 subtype on virologic and immunologic response to starting highly active antiretroviral therapy. Clin Infect Dis 48:1296-1305.

Giusti A and Penco GP (2011) Vitamin D deficiency in HIVinfected patients: A systematic review. Nutr Diet Suppl 3:101-111.

Kelley CF, Kitchen CMR, Hunt PW, Rodriguez B, Hecht FM, Kitahata M, Crane HM, Willig J, Mugavero M, Saag M et al. (2009) Incomplete peripheral CD4+ cell count restoration in HIV-infected patients receiving long-term antiretroviral treatment. Clin Infect Dis 48:787-94.

Lake JE and Adams JS (2011) Vitamin D in HIV-Infected patients. Curr HIV/AIDS Rep 8:133-141.

Laplana M, Sánchez-de-la-Torre M, Puig T, Caruz A and Fibla J (2014) Vitamin-D pathway genes and HIV-1 disease progression in injection drug users. Gene 545:163-169.

Li T, Wu N, Dai Y, Qiu Z, Han Y, Xie J, Zhu T and Li Y (2011) Reduced thymic output is a major mechanism of immune reconstitution failure in HIV-infected patients after long-term antiretroviral therapy. Clin Infect Dis 53:944-951.

Mueller NJ, Fux C, Ledergerber B, Elzi L, Schmid P, Dang T, Magenta L, Calmy A, Vergopoulos A and Bischoff-Ferrari H (2010) High prevalence of severe vitamin D deficiency in combined antiretroviral therapy-naive and successfully treated Swiss HIV patients. Aids 24:1127-1134.

Palella FJ, Baker RK, Moorman AC, Chmiel JS, Wood KC, Brooks JT and Holmberg SD (2006) Mortality in the highly active antiretroviral therapy era: Changing causes of death and disease in the HIV outpatient study. J Acquir Immune Defic Syndr 43:27-34.

Prietl B, Treiber G, Pieber TR and Amrein K (2013) Vitamin D and immune function. Nutrients 5:2502-2521.

Robbins GK, Spritzler JG, Chan ES, Asmuth DM, Gandhi RT, Rodriguez BA, Skowron G, Skolnik PR, Shafer RW and Pollard RB (2009) Incomplete reconstitution of T cell subsets on combination antiretroviral therapy in the AIDS Clinical Trials Group Protocol 384. Clin Infect Dis 48:350-361.

Selvaraj P, Harishankar M, Singh B, Banurekha VV and Jawahar MS (2012) Effect of vitamin D3 on chemokine expression in pulmonary tuberculosis. Cytokine 60:212-219.

Welz T, Childs K, Ibrahim F, Poulton M, Taylor CB, Moniz CF and Post FA (2010) Efavirenz is associated with severe vitamin D deficiency and increased alkaline phosphatase. AIDS 24:1923-1928.

Xu C, Tang P, Ding C, Li C, Chen J, Xu Z, Mao Y, Wu M and Zhao J (2015) Vitamin D receptor gene foki polymorphism contributes to increasing the risk of HIV-negative tuberculosis: Evidence from a meta-analysis. PLoS One 10:e0140634.

\section{Supplementary material}

The following online material is available for this study: Table S1 - Allelic combination of VDR functional SNPs. Table S2 - Adjusted clinical variables logistic regression model of VDR genotypes.

Table S3 - Plasma levels of 25-hydroxy vitamin D.

Associate Editor: Regina C. Mingroni-Netto

License information: This is an open-access article distributed under the terms of the Creative Commons Attribution License (type CC-BY), which permits unrestricted use, distribution and reproduction in any medium, provided the original article is properly cited. 